University of Nebraska - Lincoln

DigitalCommons@University of Nebraska - Lincoln

\title{
ECOLOGY AND HOST SPECIFICITY OF LAELAPINE MITES (ACARI: LAELAPIDAE) OF SMALL MAMMALS IN AN ATLANTIC FOREST AREA OF BRAZIL
}

\author{
Fernanda Martins-Hatano \\ Universidade do Estado do Rio de Janeiro, martinsfernanda@hotmail.com \\ Donald Gettinger \\ University of Central Arkansas, donaldgettinger@gmail.com \\ Helena G. Bergallo \\ Universidade do Estado do Rio de Janeiro
}

Follow this and additional works at: https://digitalcommons.unl.edu/parasitologyfacpubs

Part of the Parasitology Commons

\begin{abstract}
Martins-Hatano, Fernanda; Gettinger, Donald; and Bergallo, Helena G., "ECOLOGY AND HOST SPECIFICITY OF LAELAPINE MITES (ACARI: LAELAPIDAE) OF SMALL MAMMALS IN AN ATLANTIC FOREST AREA OF BRAZIL" (2002). Faculty Publications from the Harold W. Manter Laboratory of Parasitology. 680. https://digitalcommons.unl.edu/parasitologyfacpubs/680
\end{abstract}

This Article is brought to you for free and open access by the Parasitology, Harold W. Manter Laboratory of at DigitalCommons@University of Nebraska - Lincoln. It has been accepted for inclusion in Faculty Publications from the Harold W. Manter Laboratory of Parasitology by an authorized administrator of DigitalCommons@University of Nebraska - Lincoln. 


\title{
ECOLOGY AND HOST SPECIFICITY OF LAELAPINE MITES (ACARI: LAELAPIDAE) OF SMALL MAMMALS IN AN ATLANTIC FOREST AREA OF BRAZIL
}

\author{
Fernanda Martins-Hatano, Donald Gettinger*, and Helena G. Bergallo \\ Departamento de Ecologia, IBRAG, Universidade do Estado do Rio de Janeiro, Rua São Francisco Xavier, no. 524, Maracanã, Rio de Janeiro, \\ RJ, CEP: 20550-011, Brasil.e-mail: martinsfernanda@hotmail.com
}

\begin{abstract}
Mesostigmatic mites of the Laelapinae Berlese, 1892 (Acari: Laelapidae) are nidicolous arthropods that commonly occur in the fur of Neotropical small mammmals. In this 2-yr study, the laelapine acarofauna associated with the small mammal community in an area of Atlantic forest on Ilha Grande, Rio de Janeiro State, was examined, including observations on patterns of host specificity, mite dispersal, ecology, and food habits. A total of 1,347 laelapines was sampled from the pelage of 6 species of small mammals (Marmosops incanus, Nectomys squamipes, Oryzomys russatus, Rhipidomys n. sp., Oxymycterus dasytrichus, and Trinomys dimidiatus), all of which occurred exclusively in monoxenous associations with their hosts. No evidence of a blood meal was observed in the gut of the mites. With the exception of the 2 species of Tur, mite populations on hosts were entirely or nearly restricted to adult females. These results, together with some morphological characteristics of laelapines, reinforce the hypotheses that Neotropical laelapine mites are not ectoparasitic, and that females disperse by phoresy.
\end{abstract}

Mesostigmatic mites of the cosmopolitan Laelapinae Berlese, 1892 (Acari: Laelapidae) are common associates of Neotropical small mammals of the Rodentia and Didelphimorphia. In fact, these mites are usually the predominant group of arthropods sampled in the Neotropics when nonvolant small mammals are captured, etherized, and brushed. The taxonomic foundation of the Neotropical Laelapinae is well established (for the most comprehensive studies see Fonseca, 1939a, 1939b; Furman, 1972), and it is now possible to begin to develop a more comparative view of laelapine ecology and evolution. Here, we report the results of a 2-yr study of the laelapine acarofauna associated with the small mammal community in an area of Atlantic forest on Ilha Grande, Rio de Janeiro State. We include observations on patterns of host specificity, mite dispersal ecology, and food habits.

Information about the host specificity of Neotropical laelapine mites is conflicting. Pleioxenous or polyxenous associations have been reported for most laelapines where they have been extensively surveyed in northeastern Brazil (Fonseca, 1958), Panama (Tipton et al., 1966), Venezuela (Furman, 1972), and Argentina (Castro et al., 1987) or intensively surveyed in smaller studies in southeastern Brazil (Botelho and Williams, 1980; Botelho, 1981; Whitaker and Dietz, 1987; Linardi et al., 1991) and Paraguay (Whitaker and Abrell, 1987). However, after completing a large intensive survey of small mammals and their laelapine mites in the Federal District of Central Brazil, Gettinger $(1987,1992)$ concluded that laelapine mites of the genera Gigantolaelaps and Laelaps were monoxenous, each mite species associated exclusively with a separate species of host. On the island Ilha Grande, Guitton et al. (1986) reported polyxenous or pleioxenous associations for all laelapine mite species where the sample size was $>3$ individuals (12 species of laelapines were reported in 36 separate host-mite associations), but Bittencourt (1998) reported strictly monoxenous relationships between small mammals and laelapine mites on the same island. With this study, we hoped to clarify this important issue by vigilantly controlling the brushing process to avoid any sampling biases, carefully preparing indices of infestation for each

Received 25 March 2001; revised 12 July 2001; accepted 12 July 2001.

* Department of Biology, University of Central Arkansas, Conway, Arkansas 72035. e-mail: donaldg@alltel.net host-mite association, and retaining verifiable specimen vouchers of small mammal hosts.

The general life cycle of mesostigmatic mites includes egg, larva, protonymph, deutonymph, and adult male and female. However, in many laelapines the egg and even the larval stage may be suppressed, with females giving birth to larvae or even octopod protonymphs (Fonseca, 1939a, 1939b; Radovsky, 1994). All previous studies of Neotropical laelapine mites have been based on field sampling of small mammals by brushing and removing arthropods from the host skin and pelage. In general, these samples are comprised mainly of adult female mites; the males, protonymphs, deutonymphs, and larvae are usually very rare. Radovsky $(1985,1994)$ suggested that in most nidicolous laelapine species, females disperse by phoresy, which is why they are commonly found in host fur; males and immature forms are presumed to be restricted to the nest of the host. Phoresy provides an avenue of dispersal for nonvagile nidicolous microarthropods between the nests of the host mammals.

Very little information is available about the food habits of laelapine mites, but most of them are considered nidicolous ectoparasites with generalist food habits (Radovsky, 1994). Although a few laboratory studies have been done, primarily with laelapines of Old World origin (Furman, 1959; Radovsky, 1969), this broad conclusion is based on comparative morphology of the chelicerae. Although there is evidence that some laelapines have chelicerae adapted somewhat for bloodsucking, the stout chelate-dentate chelicerae of most of the Neotropical laelapine mites appear to be adapted for grasping and tearing the cuticle of small prey and are poorly formed for perforating and penetrating the skin of adult hosts (Furman, 1959; Radovsky, 1985). The male chelicerae are highly modified for the transfer of sperm and are of doubtful use in feeding. Laelapine mites are not highly specialized for blood feeding, but some species are known to take blood facultatively, even initiating wounds and abrasions (Furman, 1959, 1966; Radovsky, 1985). Reytblat (1965, in Radovsky, 1985) found that some Old World laelapines were not able to reproduce in the lab without some vertebrate blood in the diet.

We attempted to determine (1) which laelapine mite species occur on Ilha Grande and which mammalian hosts are infested, (2) how laelapine species are distributed across the small mammal community (host associations), (3) the prevalence, mean abundance, and mean intensity of mite infestation on their 


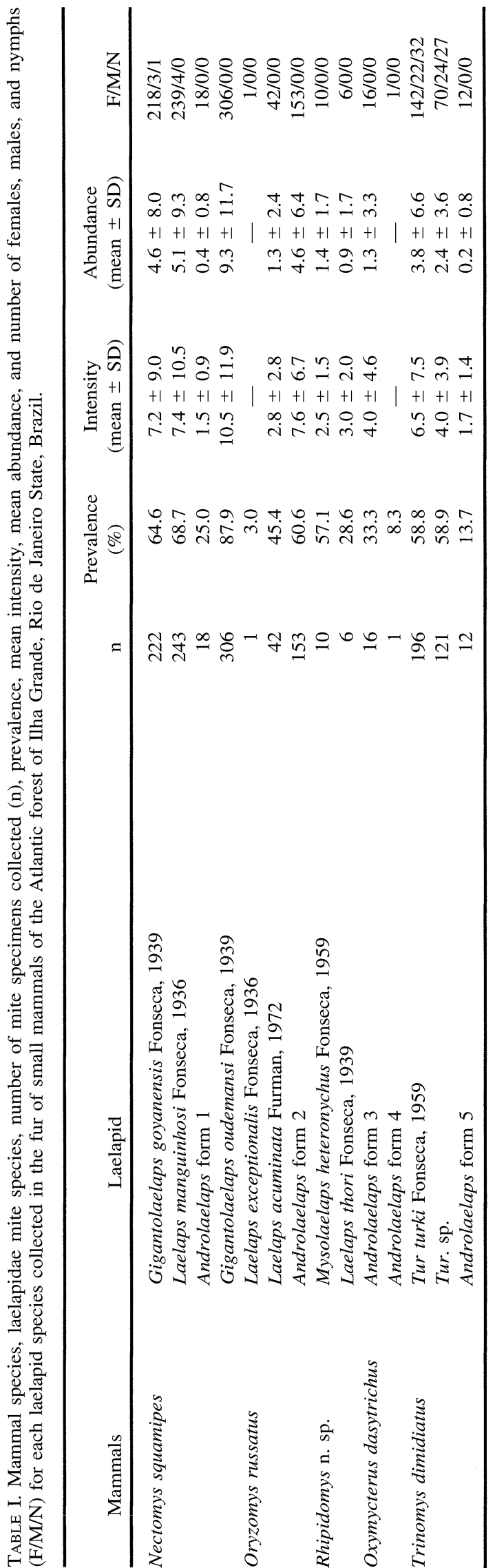

hosts, (4) the sex and life stages of mites present in host fur, and (5) whether evidence of blood feeding could be observed.

\section{MATERIALS AND METHODS}

The research was conducted from January 1998 to December 1999 in an area of Atlantic forest located in Vila Dois Rios $\left(23^{\circ} 05^{\prime}-23^{\circ} 15^{\prime} \mathrm{S}\right.$; $\left.44^{\circ} 06^{\prime}-44^{\circ} 23^{\prime} \mathrm{W}\right)$, Ilha Grande, Angra dos Reis Municipality, Rio de Janeiro State, Brazil. The average precipitation was about 2,200 mm (Central Nuclear de Angra-NUCLEN), and average annual temperature was $23 \mathrm{C}$. The general area was a complex of diverse habitats, including inundated land (brejos), brushwoods (capoeiras), orchards, hayfields, and secondary forest transected by small streams. The average height of forest canopy was about $4 \mathrm{~m}$, with taller trees rising to nearly $10 \mathrm{~m}$.

Small mammals were surveyed on a 3.24-ha grid, with 10 lines arrayed at 20-m intervals. Each line had 10 live traps (Sherman, Tomahawk, or Movarti) placed at 20-m intervals. During 3 successive nights each month, traps were set on the forest floor and baited with banana or manioc with peanut butter. Traps remained open throughout the night and were checked in the early morning.

Each small mammal was removed from the live trap and transferred to a plastic bag in which a cotton ball soaked in ether was placed. When the mammal was torpid, it was removed from the bag, identified, and marked, and the entire body was brushed with a toothbrush over a white tray. After recovery from anesthesia, the animal was released at the point of capture. The tray was washed with $70 \%$ ethyl alcohol, and all the contents (alcohol and ectoparasites) were transferred with a pipette to a vial. The plastic etherization bag was visually searched for ectoparasites. A unique toothbrush and plastic bag were reserved for each host species, and after the sample was processed, all instruments were dried with disposable paper towels to reduce the chance of contamination.

In the laboratory, vial contents were examined under a stereoscope, and laelapid mites were identified, segregated by sex and developmental stage, and counted. All individuals were examined for the presence of blood in the gut. Some mites were cleared with lactophenol, mounted on slides with Hoyer's medium, and examined under the microscope to confirm identification. Prevalence, mean intensity, and mean abundance (according to Bush et al., 1997) were determined for each ectoparasite species.

\section{RESULTS}

One species of marsupial, Marmosops incanus (Lund, 1840) (Didelphidae, $\mathrm{n}=2$ ), and 7 species of rodents were captured in this study. The rodents belonged to the Sciuridae: Sciurus aestuans Linneus, $1826(\mathrm{n}=3)$; Muridae: Nectomys squamipes (Brants, 1827) (n= 48), Oryzomys russatus (Wagner, 1848) (n $=33$ ), Rhipidomys n. sp. (Pereira et al., 2001) $(\mathrm{n}=7)$, and Oxymycterus dasytrichus (Fischer, 1814) (n = 12); Cavidae: Cavia aperea Erxleben, $1777(\mathrm{n}=1)$, and Echimyidae: Trinomys dimidiatus (Günther, 1877) $(\mathrm{n}=51)$.

Voucher specimens of mammals from Ilha Grande were karyotyped, prepared as standard skins and skeletons, and deposited at Museu Nacional do Rio de Janeiro (M. incanus MN31032, MN24399; S. aestuans MN31029; N. squamipes MN31024, MN31026, MN30516; O. russatus MN31034, MN48049, MN31033; Rhipidomys n. sp. MN31031, MN24365, MN24389; O. dasytrichus MN24929, MN42048). Voucher specimens of $T$. dimidiatus (HGB79, IG05, IG06) were deposited but have not yet been accessioned into the catalog at the Museu Nacional do Rio de Janeiro.

A total of 1,347 laelapine mites were collected, belonging to 5 genera and 15 species (Table I). No mites were found on $S$. aestuans or $C$. aperea.

Six distinct morphological forms of Androlaelaps were collected from Ilha Grande mammals, each exclusively associated 
with a single host (Table I). We used the morphospecies designation because of the confusion that exists at the species level within this broad genus in the Neotropics. The 6 forms are easily separated by a combination of mensural and meristic characters and await further study. Androlaelaps marmosops (a new species, Martins-Hatano et al., 2001) was associated with $M$. incanus, but only 2 female mites were collected from the island and population indices were not calculated. This new mite species is also a common associate of mainland populations of $M$. incanus. Only female mites of Androlaelaps were collected; no males or immatures were found (Table I). No blood was observed in the gut of these mites or any other mite species.

Prevalence, mean intensity, and mean abundance of laelapine mites are highly variable for each host species (Table I). Gigantolaelaps oudemansi had the highest prevalence $(87.9 \%)$, mean intensity (10.5 \pm 11.9$)$, and mean abundance (9.3 \pm 11.7). Laelaps exceptionalis and Androlaelaps form 4 were each represented by a single specimen, suggesting that they are rare.

In the majority of mite species, only females were collected from the fur of the hosts, although a few adult males and nymphs were occasionally found. However, the 2 species of Tur on Trinomys dimidiatus were exceptions; males and nymphal mites were collected moderately often from the host samples, although the samples were still strongly female biased.

All mite species were associated exclusively with a single host species. Only a single mite individual was found on an atypical host species (a single female Tur turki on $O$. russatus).

\section{DISCUSSION}

Dermanyssoid mites appear to have evolved to parasitism by first becoming nidicolous commensals (Radovsky, 1985). Because nests are temporary and interrupted microhabitats, an obvious adaptation is the use of the host to disperse (Radovsky, 1985). The manner of dispersion used by arthropods associated with vertebrates is one of the most important factors determining specificity, because specificity depends on ecological conditions that permit meeting between host and parasite (Ferreira, 1973; Timm, 1983). For nidicolous laelapine mites, dispersion is primarily vertical, between hosts of the same species (parents and young) that use the same nest (Radovsky, 1985). There are few chances of gene flow between laelapine mites associated with unrelated hosts; thus mite populations tend to be homogeneous and specific (Wenzel and Tipton, 1966; Timm, 1983). Their rapid life cycles promote changes in population size and differentiation with selective pressures, such as by associating with different host species (Price, 1977).

The laelapine mites observed in this study were all host specific. Each host species has an ensemble of mites that is not shared with sympatric host species, presenting a pattern corresponding to Fahrenholz's rule (Timm, 1983; Radovsky, 1985). The data corroborate results of Gettinger $(1987,1992)$ and Bittencourt (1998).

Many authors (Furman and Tipton, 1961; Tipton et al., 1966; Furman, 1972; Botelho and Williams, 1980; Guitton et al., 1986; Linardi et al., 1991; Bossi, 1996) have reported nonspecific relations between laelapine mites and their hosts. These differences could be due to (1) differences in the geographic scale and disturbance level of habitats studied (Gettinger and Ernest, 1995), (2) biological differences among the parasite populations studied (Gettinger, 1992), (3) differences in the analysis used to discriminate mite species, or (4) contamination problems during the sampling process.

The methodology applied in this study was rigorously designed to avoid contamination and exchange of mites between samples. It was evidently efficient; only 1 of 1,347 mites was found on an atypical host. However, all known methodologies have limitations, depending on the ability of collector and many other factors, e.g., the amount of time that the captured mammal stays in the trap (permitting the escape of mites) and difficulties in brushing mammals when the fur is wet. Solutions for these problems should be investigated.

Although $L$. exceptionalis (on O. russatus), A. marmosops (on $M$. incanus), and Androlaelaps form 4 (on $O$. dasytrichus) occurred at low prevalences, they are not considered accidental associations or contamination because (1) none was encountered on any other host species and (2) these mite associations are known to occur at other localities (Martins-Hatano et al., 2001; D. Gettinger and F. Martins-Hatano, unpubl. obs.).

Bossi (1996), working in a continental area of Atlantic forest (Juréia-Itatins), São Paulo State, also found very high prevalences of $G$. oudemansi with $O$. russatus, corroborating these results. In central Brazil, Gettinger (1987) found very high numbers of $G$. oudemansi infesting Oryzomys megacephalus. The 2 hosts, $O$. russatus and $O$. megacephalus, are closely related oryzomyine rodents (Musser et al., 1998) that are highly terrestrial. These elevated mite populations may be influenced by factors related to the size or placement of the nest substrates.

Two previous studies of ectoparasites and small mammals have been undertaken on Ilha Grande, and the results of the present research support many of the laelapine associations reported earlier. Guitton et al. (1986) also found Gigantolaelaps goyanensis and Laelaps manguinhosi associated with N. squamipes and found T. turki associated with $T$. dimidiatus. Bittencourt (1998) reported T. turki, Tur sp., and Androlaelaps (Haemolaelaps) form 5 on $T$. dimidiatus and found $G$. goyanensis and $L$. manguinhosi on $N$. squamipes.

The mite samples obtained were composed predominantly of females. Among species of Laelaps, Gigantolaelaps, Androlaelaps (Haemolaelaps), and Mysolaelaps, males and nymphs were absent or in low densities in host fur. This finding is consistent with the idea that males and nymphs stay in the nest of the host. Preliminary data on mites collected from nests of Oryzomys subflavus at the Parque Nacional da Restinga de Jurubatiba, Macaé, RJ (F. Martins-Hatano, unpubl. obs.) indicate that a higher number of males and nymphs of Gigantolaelaps vitzthumi can be found in nests. This finding supports the proposition of Radovsky (1994), who indicated that males and nymphs stay in the nest of the host and females disperse by phoresy. Inseminated females may represent the phoretic stage, climbing on the host for dispersal and colonization of a new nest.

Males and nymphs of T. turki and Tur sp. collected from $T$. dimidiatus were found in larger numbers than were those of the other laelapine species studied. Species of Tur are mainly associated with hystricomorph rodents of the Echimyidae (Tipton et al., 1966), unlike the other laelapine genera studied, which are primarily associated with myomorph rodents. One of the 
most distinctive characteristics of hystricomorph rodents is the production of precocious young, i.e., young that can move and feed independently at an earlier time than can young of myomorphs (Eisenberg, 1981). A hypothesis that might explain the differences in dispersion patterns between the species of mites from hystricomorph and myomorph rodents is that reproductive nests of the hystricomorphs are inhabited for much shorter periods compared with the nests of myomorphs.

Radovsky $(1969,1985)$ stated that laelapine mites feed on many items, i.e., small arthropods in the nest, ectoparasites, host scabs, open wounds, and host secretions, but in mites of most species apparently are unable to penetrate the intact skin of adult hosts. Some Old World species have been induced to feed on suckling mice and have taken free blood in the lab (Furman, 1966). However, the association between generalist-feeding mites and the host nest is favored by the large and diverse food supply that nests offer (Furman, 1959). Although these mites may take blood facultatively (Radovsky, 1985), the absence of blood in all the laelapines examined during the present study suggests that they are actually not true parasites of their rodent hosts. Nevertheless, the presence of other host tissues, such as lymph or epidermal cells, was not investigated, and further studies are necessary to clarify the kind of relationship that laelapine mites have with their hosts.

\section{ACKNOWLEDGMENTS}

We thank C. F. Rocha, J. L. Luque, M. V. Vieira, M. A. Alves, A. Peracchi, Gerald Esch, J. Whitaker, Jr., and an anonymous reviewer for helpful comments on the manuscript. We thank the coordinator and the administrative coordinator of CEADS/UERJ, C. F. D. Rocha and J. C. Dansinger, for local support. We thank K. C. Larson from the University of Central Arkansas, who made many facilities at the University and at her home available when F.M.H. was preparing slides. During the development of this study, F.M.H. received a graduate fellowship from CNPq and H.G.B. received a research grant from CNPq (No. 301372/ 95-0). This study represents a portion of the results of the Ecology, Conservation and Management of Southeastern Brazilian Ecosystems Program and of the Southeastern Brazilian Vertebrate Ecology Project, both of the Department of Ecology, UERJ.

\section{LITERATURE CITED}

BitTenCourT, E. B. 1998. Ecologia do Ectoparasitismo na Comunidade de Pequenos Mamíferos da Mata Atlântica da Ilha Grande. RJ: Composição. Prevalência. Intensidade Parasitária e Especificidade Parasito-Hospedeiro. M.S. Thesis. Universidade do Estado do Rio de Janeiro, Rio de Janeiro, Brasil, 97 p.

Bossi, D. E. P. 1996. Ectoparasitismo em pequenos mamíferos da Estação Ecológica de Juréia-Itatins. Iguape (SP). M.S. Thesis. Unicamp, Campinas, Brasil, 89 p.

Botelho, J. R. 1981. Alguns hospedeiros reais de ectoparasitos do Município de Caratinga. Minas Gerais. Brasil. Memórias do Instituto Oswaldo Cruz 76: 57-59.

—, AND P. WILLIAMS. 1980. Sobre alguns ectoparasitas de roedores silvestres do município de Caratinga. Minas Gerais. Brasil. II. Acarofauna. Memórias do Instituto Oswaldo Cruz 75: 47-51.

Bush, A. O., K. D. Lafferty. J. M. Lotz, AND A. W. Shostak. 1997. Parasitology meets ecology on its own terms: Margolis et al. revisited. Journal of Parasitology 83: 575-583.

Castro, D. Del C., R. Mauri. A. C. Cicchino, and S. Mosquera. 1987. Ectoparasitos de roedores de la provincia de Buenos Aires. Argentina (Acarina. Anoplura. Mallophaga y Suctoria). Revista de la Sociedad Entomologica Argentina 44: 317-327.

EISENBERG, J. F. 1981. The mammalian radiations. An analysis of trends in evolution, adaptation and behavior. University of Chicago Press, Chicago, Illinois, 509 p.
FerReIRA, L. F. 1973. O fenômeno parasitismo. Revista da Sociedade Brasileira de Medicina Tropical 7: 261-277.

FONSECA, F. 1939a. Notas de Acarologia XXV. Os laelaptidae gigantes. Parasitas de roedores sul-americanos; gênero e espécies novos (Acari). Memórias do Instituto Butantan 12: 7-102.

. 1939b. Notas de Acarologia XXVI. Novos estudos sobre o gênero Laelaps Koch. 1836 (Acari: Laelaptidae). Memórias do Instituto Butantan 12: 103-1938.

- 1958. Notas de Acarologia XLIV. Inquérito sobre a fauna acarológica de parasitas no nordeste do Brasil. Memórias do Instituto Butantan 28: 99-186.

Furman, D. P. 1959. Feeding habits of symbiotic mesostigmatid mites of mammals in relation to pathogen-vector potentials. American Journal of Tropical Medicine and Hygiene 8: 5-12.

. 1966. Biological studies on Haemolaelaps centrocarpus Berlese (Acarina: Laelapidae) with observations on its classification. Journal of Medical Entomology 2: 331-335.

. 1972. Laelapid mites (Laelapidae: Laelapinae) of Venezuela. Brigham Young University Science Bulletin Biological Series 27: $1-58$.

— AND V. J. Tipton. 1961. Ácaros parasitos laelaptine (Acarina: Laelaptinae) da Venezuela. Memorias Sociedad Ciencia La Salle. 21: $166-212$.

GETTINGER, D. 1987. Host associatios of Gigantolaelaps (Acari: Laelapidae) in the Cerrado Province of Brazil Central. Journal of Medical Entomology 24: 559-565.

1992. Host specificty of Laelaps (Acari: Laelapidae) in Central Brasil. Journal of Medical Entomology 29: 827-833.

- AND K. ERNEST. 1995. Small-mammal community structure and the specificity of ectoparasite associations in Central Brazil. Revista Brasileira de Biologia 55: 331-341.

Guitton, N., N. A. Araujo-filho, AND I. A. Sherlock. 1986. Ectoparasitas de roedores e marsupiais no ambiente silvestre de Ilha Grande. Estado do Rio de Janeiro. Brasil. Memórias do Insituto Oswaldo Cruz 81: 233-234.

Linardi, M. P., J. R. A. Ximenes, And C. R. Padovani. 1991. Notes on ectoparasites of some small mammals from Santa Catarina state, Brazil. Journal of Medical Entomology 28: 183-185.

Martins-Hatano, F., D. Gettinger, and H. G. Bergallo. 2001. Androlaelaps marmosops (Acari: Laelapidae), a new species associated with the mouse opossum, Marmosops incanus (Lund, 1840) in the Atlantic Forest of Rio de Janeiro State, Brazil. Revista Brasileira de Biologia (in press).

Musser, G. G., M. D. Carleton., E. M. Brothers, and A. L. Gardner. 1998. Systematic studies of oryzomyine rodents (Muridae. Sigmodontinae): Diagnoses and distributions of species formerly assigned to Oryzomys "capito." Bulletin of the American Museum of Natural History 236: 1-376.

Pereira, L. G., S. E. M. Torres, H. S. Silva, and L. Geise. Mammals of islands and surroundings of south region of Rio de Janeiro State. Boletim do Museu Nacional (in press).

RADOVSKY, F. J. 1969. Adaptive radiation in the parasitic Mesostigmata Acarologia 11: 450-483.

. 1985. Evolution of mammalian mesostigmate mites. In Coevolution of parasitic arthropods and mammals, K. C. Kim (ed.). Wiley, New York, New York, p. 441-504.

- 1994. The evolution of parasitism and the distribution of some dermanyssoid mites (Mesostigmata) on vertebrate hosts. In Mites: Ecological and evolutionary analyses of life-history patterns, M. A. Houck (ed.). Chapman \& Hall, New York, New York, p. 186217.

TiMM, R. M. 1983. Fahrenholz's rule and resource tracking: A study of host-parasite coevolution. In Coevolution, M. N. Nitecki (ed.). University of Chicago Press, Chicago, Illinois, p. 225-265.

Tipton, V. J., R. M. Altman, and C. M. Keenan. 1966. Mites of the subfamily Laelaptinae in Panama (Acarina: Laelaptidae). In Ectoparasites of Panamá, R. L. Wenzel and V. J. Tipton (eds.). Field Museum of Natural History, Chicago, Illinois, p 23-82. 
WENZEL, R. L., AND V. J. TIPTON. 1966. Some relationships between mammal host and their ectoparasites. In Ectoparasites of Panamá, R. L. Wenzel and V. J. Tipton (eds.). Field Museum of Natural History, Chicago, Illinois, p. 677-723.

Whitaker, J. O., JR., And D. B. Abrell. 1987. Notes on some ecto- parasites from mammals of Paraguay. Entomological News 98: $198-204$.

AND J. M. DIETZ. 1987. Ectoparasites and other associates of some small mammals from Minas Gerais, Brazil. Entomological News 98: 189-197. 